\title{
High-solids enzymatic hydrolysis of ball-milled corn stover with reduced slurry viscosity and improved sugar yields
}

\author{
Minsheng Lu, Junbao Li, Lujia Han and Weihua Xiao*
}

\begin{abstract}
Background: High-solids enzymatic hydrolysis has attracted increasing attentions for the production of bioethanol from lignocellulosic biomass with its advantages of high product concentration, water saving, and low energy and capital costs. However, the increase of solids content would worsen the rheological properties, resulting in heat/mass transfer limitation and higher mixing energy. To address these issues, ball milling was applied to corn stover prior to enzymatic hydrolysis, and the rheological behaviors and digestibility of ball-milled corn stover under high-solids loading were investigated.

Results: Ball milling significantly modified the physicochemical properties of corn stover. The apparent viscosity of slurries at 30\% solid loading decreased by a factor of 500 after milling for $60 \mathrm{~min}$, and the yield stress was less than $10 \mathrm{~Pa}$. The dramatic decrease of viscosity and yield stress enabled the hydrolysis process to be conducted in shake flask, and remained good mixing. Meanwhile, the estimated energy consumption for mixing during saccharification decreased by 400 -fold compared to the untreated one. The resultant hydrolysate using $10 \mathrm{FPU} \mathrm{g}^{-1}$ solids was determined to contain $130.5 \mathrm{~g} \mathrm{~L}^{-1}$ fermentable sugar, and no fermentation inhibitors were detected.

Conclusions: The proposed ball milling pretreatment improved rheological behavior and sugar yield of high-solids corn stover slurry. Ball milling enables high-solids slurry to maintain low viscosity and yield stress while obtaining a non-toxic high-concentration fermentable syrup, which is undoubtedly of great significance for inter-unit processing, mixing and downstream process. In addition, the energy input for ball milling could be balanced by the reduced mixing energy. Our study indicates ball milling a promising pretreatment process for industrial bioethanol production.
\end{abstract}

Keywords: Corn stover, Ball milling, High-solids, Enzymatic hydrolysis, Rheology

\section{Background}

Bioethanol production from lignocellulose materials is considered to be one of the solutions to improve energy structure and mitigate global climate change as its use of renewable materials such as agricultural and woody residues or energy crops. A pretreatment step using physical or chemical methods is essential to deconstruct the

*Correspondence: xwhddd@163.com

College of Engineering, China Agricultural University (East Campus), P.O. Box 191, 17 Qing-Hua-Dong-Lu, Hai-Dian District, Beijing 100083, People's Republic of China recalcitrance of the plant cell wall in order to increase the accessibility of cellulose and hemicellulose to enzymes. Then, the enzymes synergistically depolymerize the carbohydrates into monosaccharides for fermentation to bioethanol by microorganism. However, scale-up of the production of lignocellulosic ethanol still exist with some challenges, which impede the economic feasibility of the whole process [1-3].

A promising approach to improve the process economics is to increase the solids content in the stream. By increasing the solids content, the resulting products' concentration will be higher, which is beneficial for reducing 
equipment size and energy usage for heating and distillation [4]. Running at high solids consumes less water and produces less wastewater, and therefore less input for wastewater treating. In addition, cost-effective distillation requires ethanol concentration higher than $4 \%(\mathrm{w} / \mathrm{w})$, i.e., sugar concentration above $8 \%(\mathrm{w} / \mathrm{w})$, which implies that for most types of lignocellulose biomass, more than $15 \%$ of solid loadings is required [5, 6]. However, increasing solids loading is not without problems, these problems may counteract the cost savings of high-solids process. For example, due to the hydroscopicity of the lignocellulose materials and low water content at high-solids condition, most of water is retained within the porous structure (cell lumen, inter-cellular space and macro/ micropores), resulting in an increase of viscosity and yield stress, which could cause mixing and mass transfer problem. Inadequate mixing causes transfer problem for heat and enzymes, as well as local accumulation of products, resulting in a decrease of conversion efficiency [7]. Moreover, the power consumption of stirring is related to the viscosity, as higher impeller torque is required to overcome the shear stress under high-solid conditions [8], this would dramatically increase the power consumption of the impeller agitation and affect the process economy. Zhang et al. [9] reported that the energy consumption for mixing increased 1 order of magnitude when the solids loading of steam-exploded corn stover increased from 15 to $30 \%$ (79.5 and $1009.2 \mathrm{MJ} \mathrm{t}^{-1}$ slurry), which is equivalent to $9.3 \%$ and $58.6 \%$ of the thermal energy of ethanol produced, respectively, and attributed this to the increase of viscosity. Therefore, a better understanding of rheological behaviors of biomass slurry under high-solids loading would help to solve these challenges.

Early work by Pimenova and Hanley $[10,11]$ has indicated that corn stover slurries are shear thinning and yield stress fluids. The effects of solid loading, composition and particle morphology (including particle size, size distribution and aspect ratio) on the rheological properties of the biomass slurries have been reported
[12-16]. Studies have also looked at the evolution of the rheological behavior during the course of saccharification or fermentation [17-19]. In general, biomass slurries containing smaller particles exhibit lower viscosity and yield stress under same solids loading [14, 15, 20], which implies that reducing particle size may potentially improve the rheology of high-solids slurry and therefore reduce the energy consumption for mixing. Ball milling is an effective method to alter the ultrastructure of lignocellulosic biomass. Our colleague showed that ball milling significantly decreases the particle size and crystallinity of rice straw, meanwhile achieving an $82.71 \%$ glucose yield by enzymatic hydrolysis (EH) using $10 \mathrm{FPU} \mathrm{g}^{-1}$ dry solids for $48 \mathrm{~h}$ at $5 \%(\mathrm{w} / \mathrm{v})$ solids loading [21]. And ball milling can further dissociate the cross-linked cellulose-hemicellulose-lignin complex and depolymerize the cell wall polymers [22], which reduce the recalcitrance of plant cell wall and therefore may potentially improve the efficiency of $\mathrm{EH}$. However, ball milling is an energy-intensive process, and a comparison between the increased energy consumption for milling and the potentially reduced mixing energy remains unknown.

The aim of this study was to investigate the effects of ball milling on the rheological properties and enzymatic hydrolysis of corn stover under high-solids loading. Corn stover was subjected to ball milling for different time, and the rheological behaviors of ball-milled corn stover (BMCS) at 30\% solids loading were characterized. Meanwhile, high-solids EH of BMCS under different solids loading and enzyme loading was conducted. The changes of viscosity during $\mathrm{EH}$ were measured to estimate the energy consumption for stirring, and the balance between the input energy for ball milling and the reduced energy consumption for stirring was analyzed.

\section{Results and discussion}

\section{Physicochemical properties of BMCS}

The composition of BMCS is listed in Table 1. The results show that the carbohydrate and lignin content in the

Table 1 Physicochemical properties of BMCS

\begin{tabular}{|c|c|c|c|c|c|c|c|c|}
\hline & $D_{50}$ (um) & Crl (\%) & $P V^{a}\left(\mathrm{~cm}^{3} \mathrm{~g}^{-1}\right)$ & Porosity (\%) & $\begin{array}{l}\text { Bulk density } \\
\left(\mathrm{g} \mathrm{cm}^{-3}\right)\end{array}$ & Cellulose (\%) & Hemicellulose (\%) & Lignin (\%) \\
\hline BMCSO & $286.58 \pm 0.62$ & 46.52 & 2.673 & 78.88 & 0.295 & $37.5 \pm 0.3$ & $22.7 \pm 0.1$ & $18.2 \pm 0.2$ \\
\hline BMCS10 & $75.23 \pm 0.77$ & 42.37 & 2.421 & 76.96 & 0.318 & $\mathrm{NM}^{\mathrm{b}}$ & NM & NM \\
\hline BMCS20 & $32.66 \pm 0.38$ & 26.37 & 1.823 & 71.62 & 0.393 & NM & NM & NM \\
\hline BMCS30 & $16.51 \pm 0.52$ & 21.03 & 1.187 & 62.05 & 0.523 & $37.2 \pm 0.5$ & $22.3 \pm 0.3$ & $18.5 \pm 0.1$ \\
\hline BMCS60 & $12.56 \pm 0.16$ & 9.86 & 0.943 & 56.55 & 0.597 & NM & NM & NM \\
\hline BMCS120 & $14.63 \pm 0.26$ & 5.04 & 0.935 & 56.22 & 0.602 & $37.1 \pm 0.2$ & $21.9 \pm 0.1$ & $18.3 \pm 0.2$ \\
\hline
\end{tabular}

\footnotetext{
a Pore with diameter $>3 \mathrm{~nm}$, i.e., mesopore and macropore (including inter-cellular space, cell lumen and some space between particles)
}

${ }^{b}$ NM not measured 
milled samples are basically the same as the unmilled one, revealing that ball milling did not change the composition of corn stover.

As shown in Table 1, ball milling significantly reduced the particle size of corn stover. As ball milling time increases, the median particle size decreases sharply in the first $10 \mathrm{~min}$, then slowly decreases, finally remains unchanged after $30 \mathrm{~min}$. The $D_{50}$ of BMCS0/BMCS10 is higher than $50 \mu \mathrm{m}$ which is still at tissue scale, while the $D_{50}$ of BMCS20/30/60/120 reaches cellular scale with particle size less than $50 \mu \mathrm{m}[21,23]$, indicating that the intact structure of cell wall has been destroyed.

The PV of corn stover reduced from 2.673 to $0.935 \mathrm{~cm}^{3}$ $\mathrm{g}^{-1}$, while the porosity decreased from 78.88 to $56.22 \%$, after 120 min of ball milling (Table 1). The PV and porosity of BMCS decrease slightly at the first $10 \mathrm{~min}$, then sharply decrease within 10-60 min, and finally reach a plateau. The cell lumen represents the largest scale of porosity as its size is normally in the range of tens of micrometers [24]. Results showed that pores with diameter ranging from 10 to $100 \mu \mathrm{m}$ in BMCS0 occupy $76.0 \%$ of the total pore volume, while BMCS120 only occupies $19.2 \%$, indicating that cell lumen occupy most of the PV of BMCS0. These results demonstrate that, at first $10 \mathrm{~min}$, the intact structure of cell walls was slightly broken as the fragmentation could only reach tissue scale. Within 10-60 min, the fragmentation came to cellular scale, with a severe damage to the macropores (especially cell lumen and inter-cellular space), resulting in a sharp decrease of PV and porosity. When milling more than $60 \mathrm{~min}$, there were basically no intact cell lumen, and therefore, the PV/porosity remained unchanged. These results are consistent with the previous analysis of the particle size.

The XRD patterns of BMCS are shown in Fig. 1. The results demonstrate that the crystal peaks, [101], [002] and [040], gradually decrease or even disappear with the increase of milling time. The CrI determined by peak height method is listed in Table 1, and it can be found that ball milling significantly reduced the crystallinity of corn stover. The $\mathrm{CrI}$ of $\mathrm{BMCS} / 10$ remains relatively high (46.52\%/42.37\%) and then drops sharply, and the CrI of BMCS120 is $5.04 \%$, indicating the damage of ball milling goes deeper and deeper with processing time prolonging.

\section{Rheological behavior of BMCS slurries: apparent viscosity and yield stress}

For traditional thermochemical pretreated corn stover, the upper limit of solids content that can be effectively mixed in a conventional stirred tank reactor is $12-15 \%$ [25], and $\mathrm{EH}$ at $30 \%$ solids loading is relatively difficult to achieve at laboratory scale. However, we found that the BMCS slurries remained fluidity at up to $30 \%$ solids

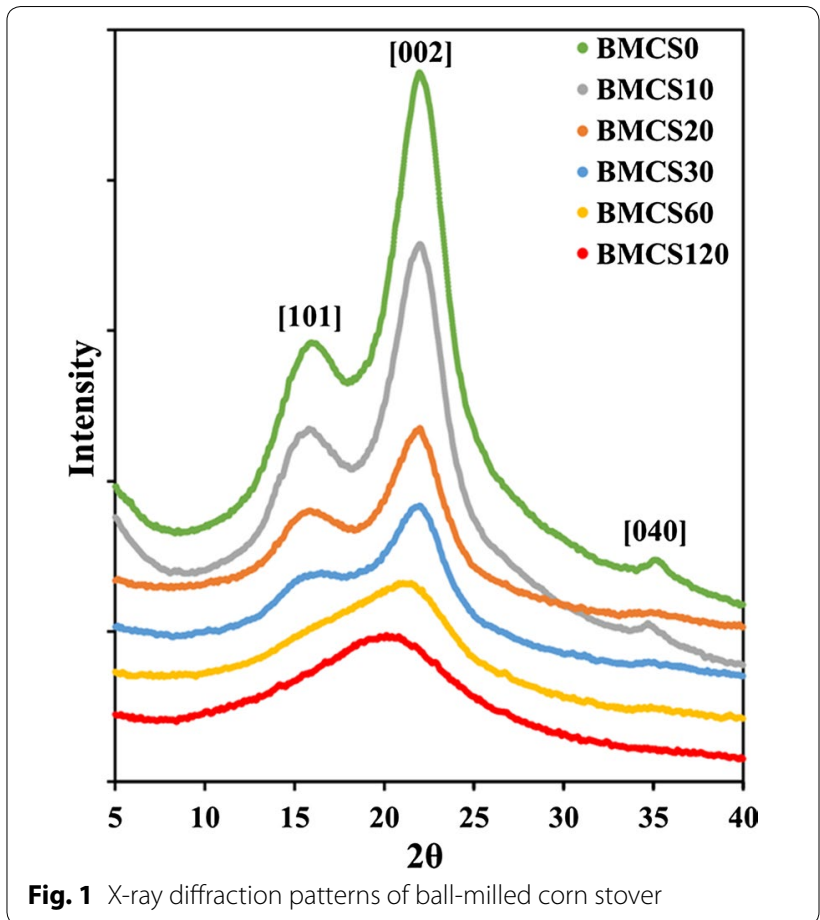

loading. Therefore, the rheological behaviors of BMCS slurries at $30 \%$ solids loading were measured within a logarithmically increasing shear rate between 0.01 and $100 \mathrm{~s}^{-1}$. The apparent viscosity varied greatly at different shear rates, exhibiting shear thinning behavior (see Additional file 1: Figure S1, for more details). For better comparison, the apparent viscosity at $\gamma_{\text {eff }}=25.12 \mathrm{~s}^{-1}$ was selected and plotted as a function of milling time, and the results are shown in Fig. 2a. It can be seen that the apparent viscosity and yield stress decrease dramatically with increasing milling time. For example, ball milling for 30 min reduced the apparent viscosity of slurry at $30 \%$ solids loading by about 300 times, further extending milling time to 120 min only reduced by around 10 times. According to the analysis in "Methods" section, the significant decrease of viscosity might have potential benefit for reducing the mixing energy during high-solids $\mathrm{EH}$, this will be discussed later. It can be found that the yield stress of BMCS60/BMCS120 is less than $10 \mathrm{~Pa}$ (Fig. 2a). $10 \mathrm{~Pa}$ is considered to be a critical value below which the slurry behaves as a pourable liquid and could be easily pumped between different process units [18]. Previous studies reported a yield tress of about $1000 \mathrm{~Pa}$ for dilute acid-pretreated corn stover at $20 \%$ solids loading [18] and of around $1500 \mathrm{~Pa}$ for untreated and dilute acidpretreated corn stover at 30\% solids loading [14], which are higher than BMCS by several orders of magnitude. The dramatic decrease in apparent viscosity and yield stress may be attributed to the following two aspects. 

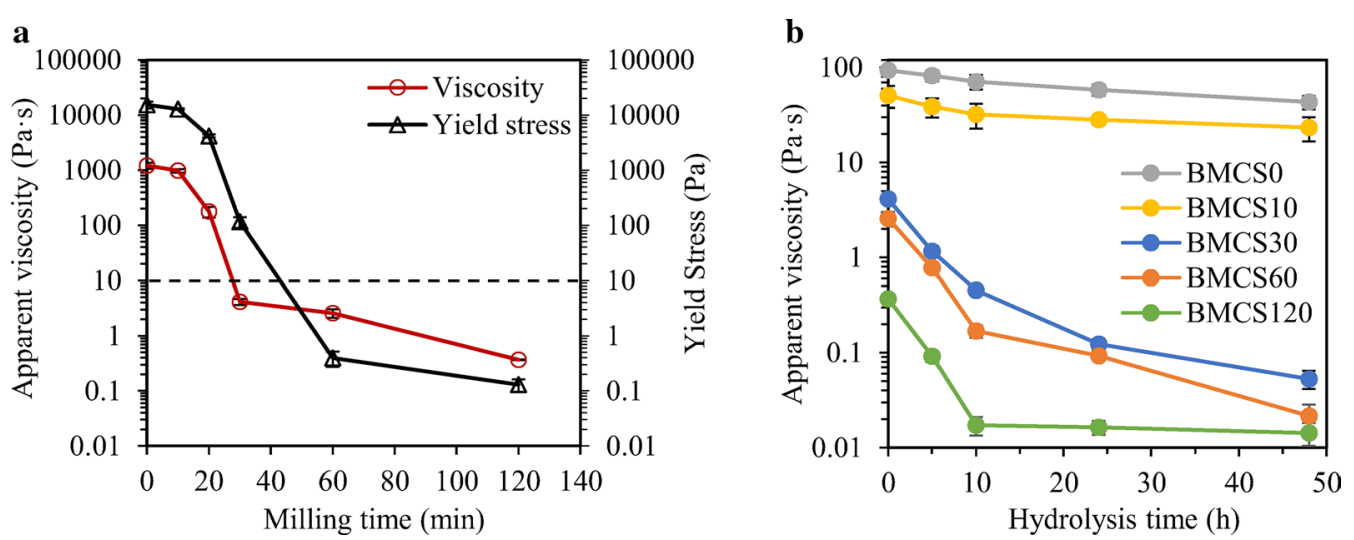

Fig. 2 Rheological parameters at 30\% solids loading a as a function of milling time, the horizontal-dashed line indicates the yield stress threshold (10 Pa) below which the slurry is pourable and pumpable; $\mathbf{b}$ at different enzymatic hydrolysis time, the solids loading of BMCSO and BMCS10 is $20 \%$. Apparent viscosity at a shear rate of $25.12 \mathrm{~s}^{-1}$ was used

The entanglement between particles alleviated due to the significant decrease of particle size, thus reduced the apparent viscosity and yield stress $[14,20]$. Another factor was the increased free water amount in slurries due to the decreased porosity (see Fig. 5 and Additional file 1 : Table S1, for more details), which increased the lubrication between particles and reduced friction, thereby reduced the apparent viscosity and yield stress [14].

Figure $2 \mathrm{~b}$ presents the changes in apparent viscosity as enzymatic hydrolysis proceeds for corn stover slurry with $30 \%$ solids loading. The apparent viscosity decreased as the hydrolysis process progressed. The decrease of viscosity could be explained by the decreased insoluble solid content and the modified particle properties as hydrolysis progressed $[18,19]$. The viscosity during EH was used to estimate the energy consumption for mixing according to the theory in "Methods" section, and this is discussed in the next section.

\section{Energy balance for ball milling and mixing}

The energy consumption of ball milling and the required mixing energy during EH are shown in Table 2. The results demonstrate that the energy required for ball milling increases with increasing milling time, and the energy input for BMCS120 reaches $19.34 \mathrm{MJ} \mathrm{kg}^{-1} \mathrm{DM}$ (dry matter). On the contrary, the required mixing energy during high-solids $\mathrm{EH}$ decreases with increasing milling time, due to the dramatic decrease of viscosity after ball milling. The mixing energy consumption of BMCS0 is $8.23 \mathrm{MJ} \mathrm{kg}{ }^{-1} \mathrm{DM}$, which is higher than that of the thermochemical pretreated biomass (Table 2) [8, 9, 26, 27]. This could be attributed to the higher viscosity, and the lower liquefaction rate (i.e., EH rate) and digestibility of untreated corn stover (BMCS0). In fact, a strict comparison between energy consumption during $\mathrm{EH}$ for different pretreated substrates is difficult because different stirring tank, stirring speed, solid loading and hydrolysis time all affect the energy consumption for mixing. In this study, after milling for $10 \mathrm{~min}$, the energy consumption for mixing was reduced to $3.69 \mathrm{MJ} \mathrm{kg}^{-1} \mathrm{DM}$. And further prolonging the milling time to $30 \mathrm{~min}$, the mixing energy was sharply decreased to $0.037 \mathrm{MJ} \mathrm{kg}^{-1} \mathrm{DM}$. To calculate the energy consumption balance between ball milling and mixing, the increased energy due to ball milling and the reduced mixing energy due to decreased viscosity based on BMCS0 were compared, and the results are shown in Fig. 3. The results show that when the milling time is less than $30 \mathrm{~min}$, the increased energy consumption for milling is less than the reduced mixing energy. For example, the increased energy consumption of BMCS30 is $4.16 \mathrm{MJ} \mathrm{kg}^{-1} \mathrm{DM}$, while the reduced mixing energy (based on BMCS0) is $8.19 \mathrm{MJ} \mathrm{kg}^{-1}$ DM. However, the increased energy consumption could not be offset by the reduced mixing energy when prolonging milling time to $60 \mathrm{~min}$ or $120 \mathrm{~min}$. In terms of glucose yield, the results show that the glucose yield increases to $23.3 \%, 49.4 \%$ and $55.3 \%$ for BMCS10, BMCS20 and BMCS30, respectively. For BMCS60, the increased energy consumption for milling is basically the same as the reduced mixing energy, while the glucose yield increased by $287 \%$ (based on BMCS0). Increasing the milling time to 120 min obtains limited improvement in glucose yield, but doubles the energy consumption of milling.

Ball milling is considered to be an economically unfeasible pretreatment method because of its high energy consumption [28-30]. However, when the EH process is running at high solids, ball milling could significantly reduce the viscosity of the slurry, thus reducing the mixing energy and offset part of the energy consumption for milling, which is of positive implications for the feasibility 
Table 2 Energy consumption of ball milling, and mixing energy during high-solids EH

\begin{tabular}{|c|c|c|c|c|c|c|c|}
\hline Substrate & $\begin{array}{l}\text { Milling } \\
\text { energy } \\
\left.\text { (MJ kg } \mathrm{kg}^{-1} \mathrm{DM}\right)\end{array}$ & Reactor & $\begin{array}{l}\text { Hydrolysis } \\
\text { conditions }\end{array}$ & $\begin{array}{l}\text { Solids loading } \\
\text { (w/w) }\end{array}$ & $\begin{array}{l}\text { Mixing } \\
\text { energy } \\
\left.\text { (MJ kg } \mathrm{kg}^{-1} \mathrm{DM}\right)\end{array}$ & Glucose yield (\%) & Refs. \\
\hline \multirow{3}{*}{$\begin{array}{l}\text { Steam-exploded } \\
\text { CS }\end{array}$} & \multirow[t]{3}{*}{ NA } & \multirow[t]{3}{*}{$5 \mathrm{~L}$, helical impeller } & \multirow{3}{*}{$\begin{array}{l}7 \mathrm{FPU} \mathrm{g}^{-1} \mathrm{DM}, \\
72 \mathrm{~h}, \\
120 \mathrm{rpm}\end{array}$} & $20 \%$ & 0.57 & 68 (ethanol) & \multirow[t]{3}{*}[9]{} \\
\hline & & & & $25 \%$ & 1.36 & 64.8 (ethanol) & \\
\hline & & & & $30 \%$ & 3.36 & 52.1 (ethanol) & \\
\hline $\begin{array}{l}\text { Steam-exploded } \\
\text { spruce }\end{array}$ & NA & $\begin{array}{l}2.5 \mathrm{~L} \text {, blade impel- } \\
\text { ler }\end{array}$ & $\begin{array}{l}20 \mathrm{FPU} \mathrm{g} \mathrm{g}^{-1} \text { glucan, } \\
96 \mathrm{~h}, \\
300 \mathrm{rpm}\end{array}$ & $10 \%$ & $\sim 1.7$ & $\sim 58$ & {$[26]$} \\
\hline \multirow{3}{*}{$\begin{array}{l}\mathrm{SO}_{2}+\text { steam- } \\
\text { exploded spruce }\end{array}$} & \multirow[t]{3}{*}{ NA } & \multirow{3}{*}{$\begin{array}{l}3 \mathrm{~L} \text {, anchor impel- } \\
\text { ler }\end{array}$} & \multirow{3}{*}{$\begin{array}{l}0.1 \mathrm{~g} C \text { CTec } 2 \mathrm{~g}^{-1} \\
\text { DM, } \\
48 \mathrm{~h}, \\
10 \mathrm{rpm}\end{array}$} & $10 \%$ & 0.116 & $\sim 34$ & \multirow[t]{3}{*}[8]{} \\
\hline & & & & $15 \%$ & 0.135 & $\sim 28$ & \\
\hline & & & & $20 \%$ & 0.272 & $\sim 24$ & \\
\hline $\begin{array}{l}\text { Steam-exploded } \\
\text { sugarcane } \\
\text { bagasse }\end{array}$ & NA & $3 \mathrm{~L}$, dual-impeller & $\begin{array}{l}10 \mathrm{FPU} \mathrm{g}^{-1} \mathrm{DM}, \\
96 \mathrm{~h}, \\
470 \mathrm{rpm}\end{array}$ & $10 \%(w / v)$ & $3.2-7.53$ & $\sim 60-75$ & {$[27]$} \\
\hline BMCSO & 0 & \multirow[t]{5}{*}{$7 \mathrm{~L}$, helical impeller } & \multirow{5}{*}{$\begin{array}{l}10 \mathrm{FPU} \mathrm{g}^{-1} \mathrm{DM}, \\
48 \mathrm{~h}, \\
55 \mathrm{rpm}\end{array}$} & $20 \%^{\mathrm{a}}$ & 8.23 & 14.3 & \multirow[t]{5}{*}{ This study } \\
\hline BMCS10 & 0.66 & & & $20 \%^{\mathrm{a}}$ & 3.69 & 23.3 & \\
\hline BMCS30 & 4.16 & & & $30 \%$ & 0.037 & 49.4 & \\
\hline BMCS60 & 9.63 & & & $30 \%$ & 0.021 & 55.3 & \\
\hline BMCS120 & 19.34 & & & $30 \%$ & 0.003 & 58.4 & \\
\hline
\end{tabular}

NA not applicable

a BMCS0 and BMCS10 with $30 \%$ solids loading was hard to handle, so the data at $20 \%$ were used instead

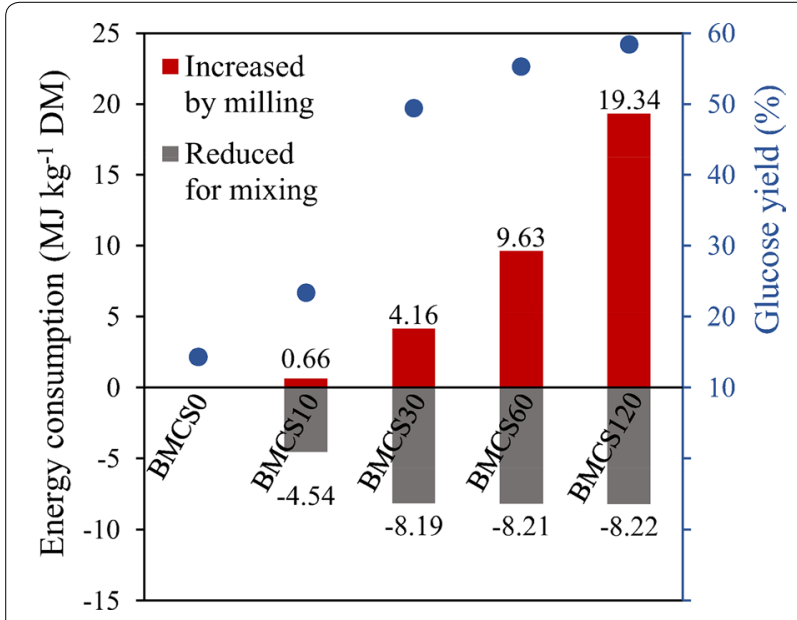

Fig. 3 Energy balance between ball milling and mixing. The reduced energy consumption for mixing was calculated based on BMCSO, for example, BMCS30: $0.037-8.23=-8.19$

of ball milling as a pretreatment method. The results also highlight the importance of considering the mixing energy consumption when conducting high-solids EH.

\section{High-solids enzymatic hydrolysis}

Given that ball milling could significantly reduce the viscosity and yield stress of the high-solid slurry, and made the slurry meet the industrial requirements of pourability and pumpability. We then evaluated the digestibility of BMCS at high-solids loading. Because BMCSO and BMCS10 behaved as wet granules like material at $20 \%$ and $30 \%$ solids loading, and the liquefaction was insufficient, which made sampling difficult, therefore, sugar data under these conditions could not be obtained.

The sugar yield of BMCS under different enzyme loading and different solids loading is shown in Fig. 4a. Results show that increasing milling time could increase the sugar yield under different solids loading. In specific, at enzyme loading of $10 \mathrm{FPU} \mathrm{g}^{-1}$ solids and solids loading of $10 \%$, the glucose yield increased from $19.9 \%$ for BMCS0 to $57.3 \%$ for BMCS30, and further increased to $72.6 \%$ for BMCS60. Further increasing milling time to $120 \mathrm{~min}$, glucose yield only increased to $77.1 \%$, suggesting that there is little value to mill for more than $60 \mathrm{~min}$, as ball milling is a high energy consumption process. In addition, we found that the enzymatic hydrolysate contained considerable cellobiose, indicating that the fermentable monosaccharides can be further improved by increasing the proportion of related enzymes. The increase of glucose yield may be a combination of the increase of specific surface area (SSA), the decrease in cellulose crystallinity and degree of polymerization (DP), and the dissociation of the cross-linked cellulose-hemicellulose-lignin complex after ball milling $[21,22,31]$. The increase of SSA, the decrease of DP, and the dissociation of the combination between lignin and 

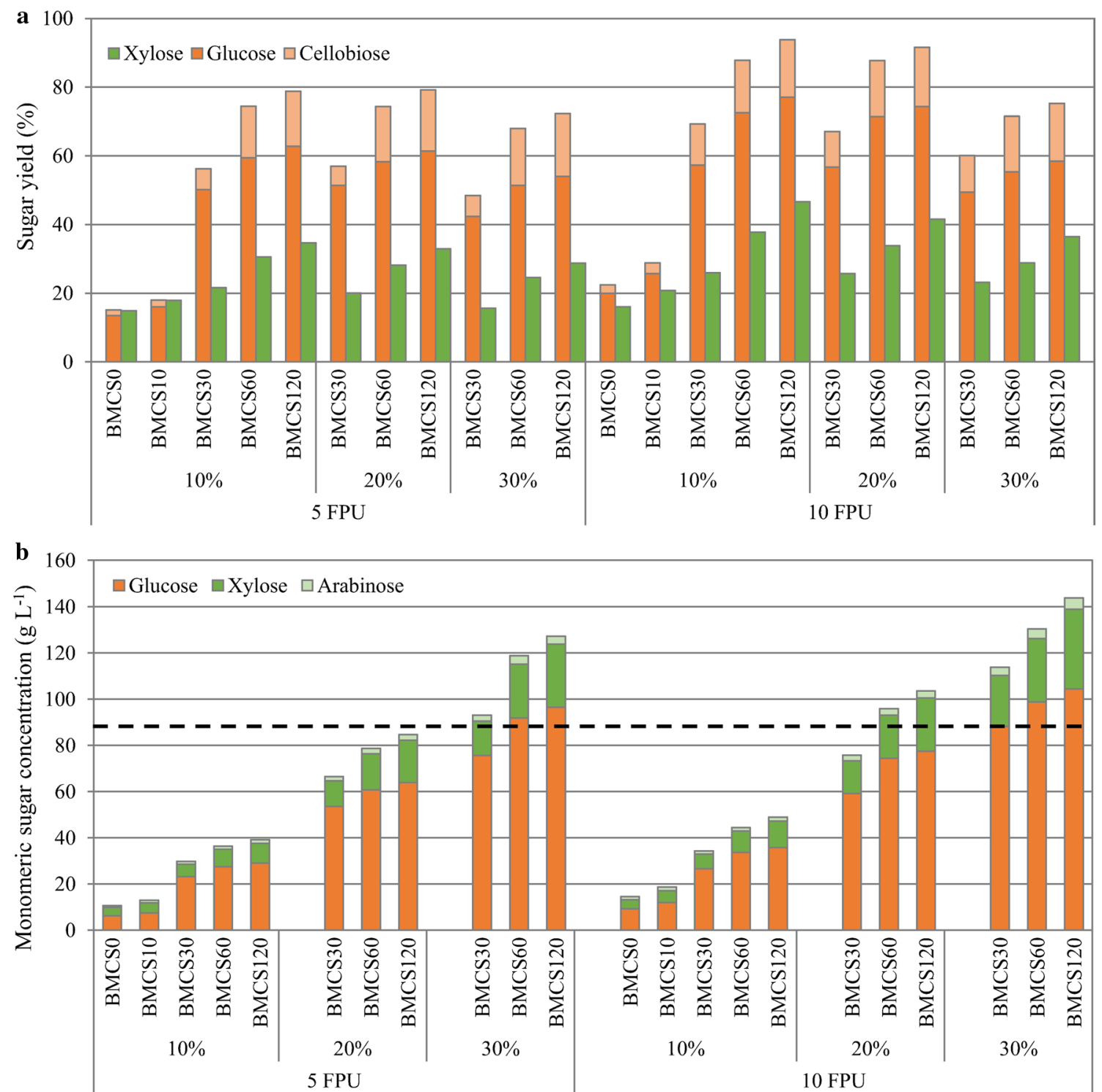

Fig. 4 Enzymatic hydrolysis of BMCS at different solids loading with different enzyme loading. Results for a sugar yield and $\mathbf{b}$ monomeric sugar concentration. The horizontal-dashed line indicates the monomeric sugar concentration threshold $(87 \mathrm{~g} / \mathrm{L})$ above which the distillation of ethanol is cost-effective (assume an ethanol yield of $0.5 \mathrm{~g} / \mathrm{g}$ glucose)

carbohydrates expose more reactive site for enzyme to hydrolysis, and the loose disordered structure of amorphous cellulose is more active, thus boosts the $\mathrm{EH}$ of corn stover. The positive effect of ball milling on the rheological behavior and enzymatic hydrolysis of corn stover slurries could be explained using a schematic diagram shown in Fig. 5.

As mentioned above, cost-effective distillation requires an ethanol concentration above $4 \%(w / w)$, i.e., fermentable sugar concentration higher than $8 \%(w / w)$ (corresponding to around $87 \mathrm{~g} \mathrm{~L}^{-1}$ ). It can be seen from Fig. $4 \mathrm{~b}$ that the total monomeric sugar concentration for BMCS30/BMCS60/BMCS120 at 30\% solids loading is still higher than $87 \mathrm{~g} \mathrm{~L}^{-1}$ after reducing enzyme loading from $10 \mathrm{FPU} \mathrm{g}^{-1}$ solids to $5 \mathrm{FPU} \mathrm{g}{ }^{-1}$ solids, while for $20 \%$ solids loading, the results are different. After reducing the enzyme loading, the glucose yield of BMCS30 and BMCS60 at 20\% solids loading decreases from $57.3 \%$ and $72.6 \%$ to $51.4 \%$ and $58.3 \%$, respectively, but the decrease of yield is less for $30 \%$ solids loading. Future work should be carried out to optimize the 

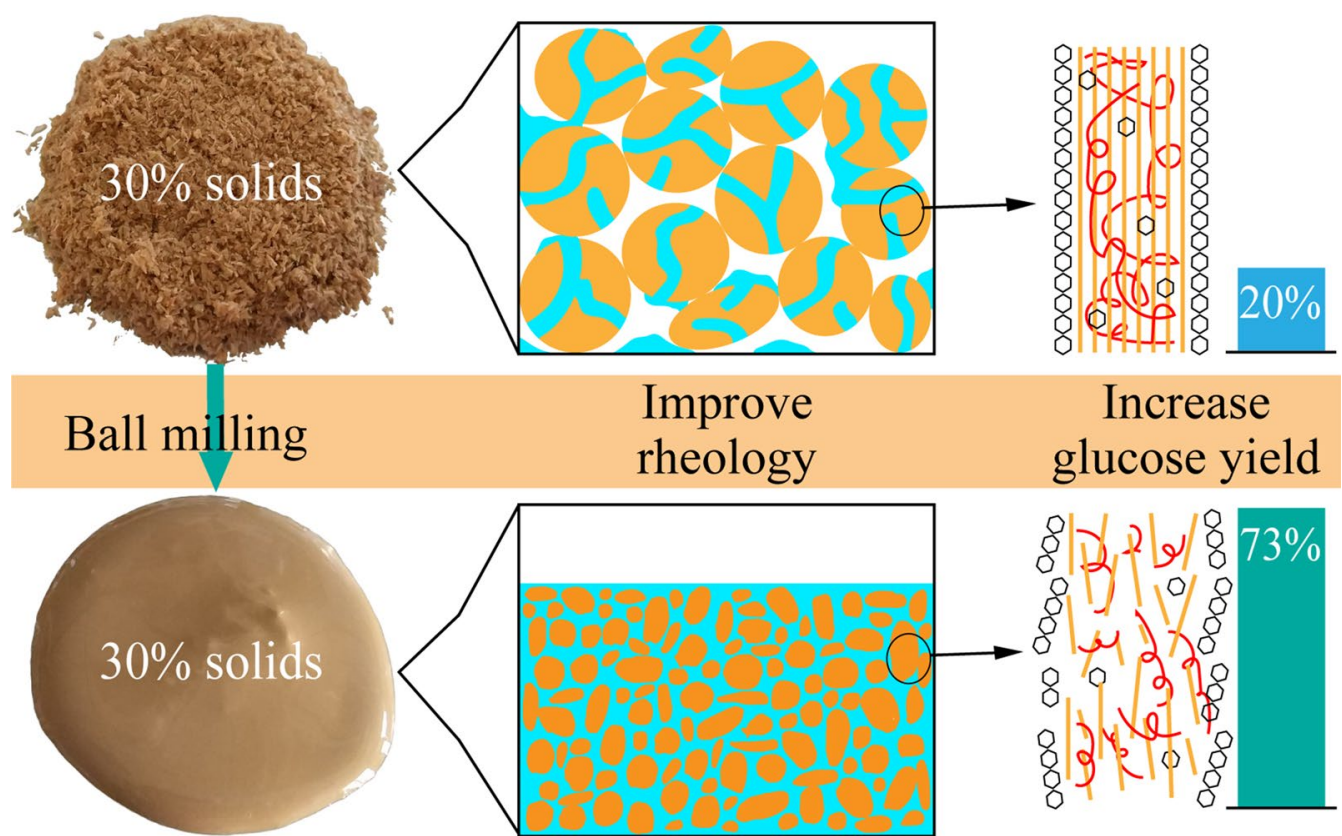

Fig. 5 Schematic diagram of the effect of ball milling on the rheological properties and digestibility

enzyme loading and enzyme ratio (e.g., add xylanase) to further increase the sugars' yield.

The change of glucose yield with solids loading is shown in Fig. 6a. It can be seen from the figure that the so-called 'solids effect', that is, the sugar yield decrease at high-solids loading, has been demonstrated in previous reports on high-solids $\mathrm{EH}$ of different pretreated lignocellulosic substrates [5, 32-34]. While in this study, the glucose yield of BMCS was basically unchanged when the solids loading increased from
10 to $20 \%$, and further increased the solids loading to $30 \%$, the glucose yield was significantly reduced. These results indicate that ball milling can raise the threshold of solids effect, in other words, alleviate the solids effect to some extent. The glucose yield appears to begin to decrease when the glucose concentration exceeds $60 \mathrm{~g}$ $\mathrm{L}^{-1}$ (Fig. 6b), so the solids effect seems to be caused by end-product inhibition. Future works will be carried out to apply the simultaneous saccharification and fermentation (SSF) to this high-solid process to
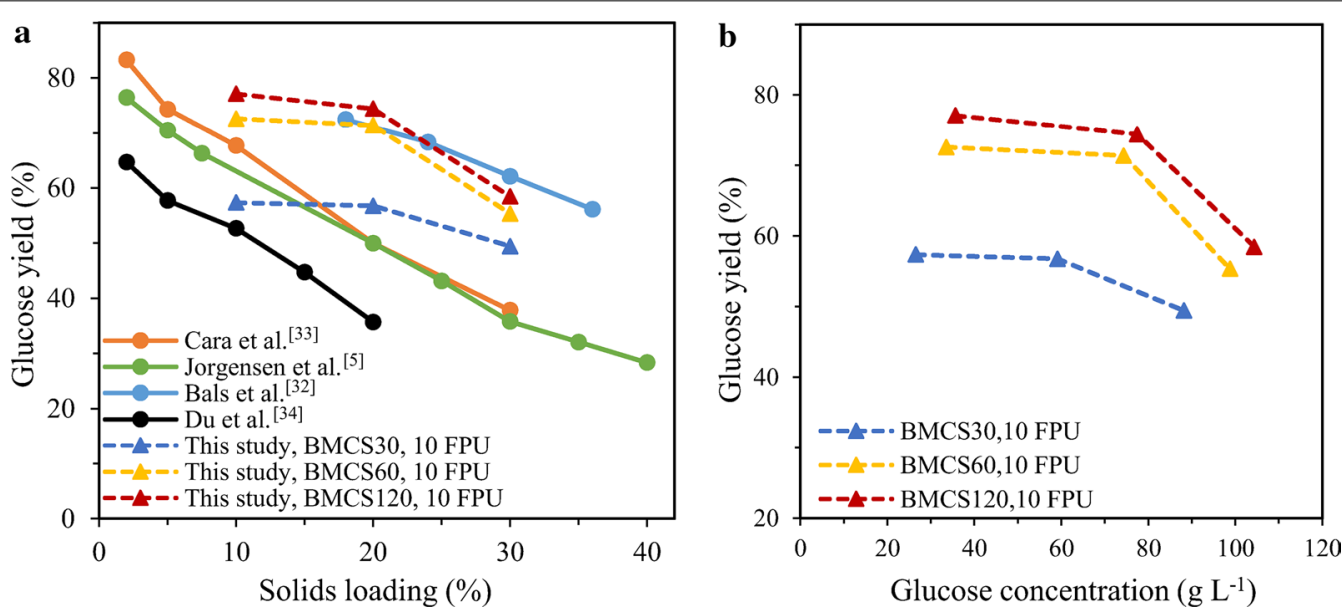

Fig. 6 Effect of solids loading and glucose concentration on glucose yield. a Solids loading (data collected from several publications) and $\mathbf{b}$ glucose concentration 
alleviate the reduction of sugar yield caused by product inhibition.

The EH kinetic results show that the glucose yield of BMCS reached a maximum after $10 \mathrm{~h}$ (Additional file 1: Figure S2), which is meaningful for shortening the production time of cellulosic ethanol. In addition, inhibitors such as furfural, HMF and acetic acid were not detected during the sugar analysis. Conventional thermochemical or physicochemical pretreatment may produce these inhibitors [35]. Running at high-solids potentially implies increased concentration of these inhibitors and thus severely affects the fermentability of the microorganisms. Detoxification by overliming, ion exchange, zeolites or laccase enzyme is usually required before saccharification [36], or a rinsing step followed by dehydration is applied to eliminate the effects of inhibitors, which makes the entire process costly and some soluble sugar might be washed away. The production of a high-concentration sugar syrup free of fermentation inhibitors is very attractive to the downstream fermentation and distillation process.

\section{Conclusions}

Ball milling significantly modified the physicochemical properties of corn stover. The dramatic decrease of particle size leaded to a decrease of entanglement between particles, and the increase of free water enhanced the lubrication; these two factors significantly reduce the viscosity and yield stress of BMCS slurries. As a result, ball milling allowed corn stover to successfully hydrolyze at up to $30 \%$ solids loading in a shake flask and maintain good mixing. Ball milling significantly decreased the crystallinity and DP of corn stover, and dissociated the cross-linked cellulose-hemicellulose-lignin complex, thus boosted the glucose yield at high-solids $\mathrm{EH}$, and the resultant hydrolysate was demonstrated to contain fermentable sugar concentration exceeding $87 \mathrm{~g} \mathrm{~L}^{-1}$ (minimum sugars' concentration for cost-effective ethanol distillation), and no toxic fermentation inhibitors were detected. Furthermore, the energy balance analysis demonstrated that the increased energy used for ball milling could be balanced by the reduced mixing energy.

\section{Methods}

\section{Corn stover and enzyme preparation}

The corn stover used in this study was collected from Shangzhuang Experimental Station of China Agricultural University. The whole crop residues were air-dried and then cut into $2-3 \mathrm{~cm}$ length before drying at $40{ }^{\circ} \mathrm{C}$ for $48 \mathrm{~h}$, and finally milled to pass through a $1-\mathrm{mm}$ screen using an RT-34 milling machine (Hongquan Pharmaceutical Machinery Ltd., Hong Kong, China). The sample obtained here was denoted as BMCSO.
The enzyme preparation used in this study was Novozymes Cellic CTec2, which was purchased from SigmaAldrich (St. Louis, MO, USA). The filter paper activity of CTec2 was determined to be $160.8 \mathrm{FPU} \mathrm{mL}^{-1}$. The protein content of CTec 2 was measured by the Bradford method using bovine serum albumin as a standard [37], and the protein content was determined to be $106.2 \mathrm{mg} \mathrm{mL}^{-1}$.

\section{Ball milling}

The milling was conducted in a vibratory ball mill machine equipped with 2-L $\mathrm{ZrO}_{2}$ chamber (CJM-SY-B, Qinhuangdao Taiji Ring Nano Ltd., Hebei, China). The BMCS0 sample was mixed with $\mathrm{ZrO}_{2}$ ball $(6-10 \mathrm{~mm}$ diameter) with a volume ratio of $1: 2$ and a filling rate of $30 \%$, then milled for $10,20,30,60$ and $120 \mathrm{~min}$, the resulting powders were denoted as BMCS10, BMCS20, BMCS30, BMCS60 and BMCS120, respectively. During the ball milling process, the temperature was controlled below $20^{\circ} \mathrm{C}$ using a cooling system.

\section{Characterization of physicochemical properties Composition analysis}

The composition of BMCS was measured by a two-step acid hydrolysis method according to National Renewable Energy Laboratory (NREL) standard analysis procedure [38].

\section{Distribution of particle size}

A laser scattering particle size analyzer, Model Mastersizer 3000 (Malvern Instruments Ltd., United Kingdom), was used to measure the particle size distribution of BMCS by dry mode. The median particle size $\left(D_{50}\right)$ was regarded as the average particle size of the sample.

\section{Porous structure}

The porous structure of the BMCS, such as pore volume (PV) and porosity were measured by an AutoPore-9500 mercury porosimeter (Micromeritics Instrument Ltd., United States) using a powder sample tube with the pressure ranges from 0.52 Pisa to 60,000 Pisa (corresponding to a pore size range of $347,263-3 \mathrm{~nm}$ ) and an equilibrium time of $10 \mathrm{~min}$.

\section{$X$-ray diffraction}

The X-ray diffraction (XRD) pattern was obtained by a Bruker D8 advance X-ray diffractometer (Bruker AXS Inc., WI, Germany) with a $\mathrm{Cu} \mathrm{K} \alpha$ radiation source operated at $40 \mathrm{kV}$ and $40 \mathrm{~mA}$. The scanning range of $2 \theta$ was from $5^{\circ}$ to $40^{\circ}$, with a scanning speed of $2^{\circ} \mathrm{min}^{-1}$ and a step size of $0.02^{\circ}$. The crystallinity index (CrI) of BMCS was determined by the peak height method and the formula was as follows [39]: 


$$
\mathrm{CrI}=\left(I_{002}-I_{\mathrm{am}}\right) / I_{002} \times 100,
$$

where $I_{002}$ is the intensity of [002] peak at approximately $2 \theta=22.5^{\circ}$, and $I_{\mathrm{am}}$ the intensity of the minimum between the [002] and the [101] peaks at around $2 \theta=18^{\circ}$.

\section{High-solids enzymatic hydrolysis}

Commercial enzyme preparation Novozymes Cellic $\mathrm{CTec} 2$ was used for high-solids EH of BMCS. The digestion was carried out in a $250-\mathrm{mL}$ shake flask loaded with 60 g BMCS slurry with $10 \%, 20 \%$ and $30 \%$ solids content prepared by citrate buffer $(\mathrm{pH} 4.8)$ using an enzyme loading of 5 and $10 \mathrm{FPU} \mathrm{g}^{-1}$ solids, and tetracycline hydrochloride $\left(0.08 \mathrm{~g} \mathrm{~L}^{-1}\right)$ was added to avoid microbial interference. $\mathrm{EH}$ was performed in a shaking water bath operating at $150 \mathrm{rpm}$ and $50^{\circ} \mathrm{C}$.

After digestion for $2 \mathrm{~h}, 5 \mathrm{~h}, 10 \mathrm{~h}, 24 \mathrm{~h}, 48 \mathrm{~h}$ and $72 \mathrm{~h}$, the well-mixed solid-liquid mixture was taken for rheological measurement and products' analysis. Part of the samples was subjected to apparent viscosity measurement to estimate the energy consumption of stirring during hydrolysis process. The sugars and byproducts analysis was based on NREL standard analysis procedure [40]; deducting the sugar concentration in the enzyme blank to obtain the final result. Sugar yield was defined as the percentage of monosaccharide released during digestion process based on the theoretical maximum.

\section{Rheological measurement}

The rheological measurement of corn stover slurries before and after enzymatic hydrolysis was carried out with an AR-G2 rheometer (TA Instruments) using a $25-\mathrm{mm}$ serrated parallel plate geometry with a $1.5 \mathrm{~mm}$ gap. Plate temperature was set to $50^{\circ} \mathrm{C}$ in all cases.

The apparent viscosity of slurries was measured using flow sweep mode. The transducers were initialized (Conditioning Transducer) before data acquisition, ensuring that the normal force and torque transducer were in Force Rebalance Transducer (FRT) mode, the appropriate torque range was selected, and the normal force and torque were zeroed. The shear rate was logarithmically increased from 0.01 to $100 \mathrm{~s}^{-1}$. All measurements were carried out in, at least, triplicates with fresh samples.

Unlike model extrapolation method [14], the yield stress reported here was measured using an AR-G2 rheometer in oscillatory amplitude mode. Similarly, the transducers were initialized (Conditioning Transducer) before data acquisition. The strain amplitude was logarithmically increased from 0.01 to $100 \%$ at a frequency of $1 \mathrm{~Hz}$. The yield stress $\left(\tau_{y}\right)$ was calculated as the maximum value of $\tau=G^{\prime} \cdot \gamma$, where $G^{\prime}$ is the elastic modulus of the slurry, and $\gamma$ the strain amplitude [18]. All measurements were carried out in, at least, triplicates with fresh samples.

\section{Calculation of energy consumption for ball milling and stirring}

The energy consumption of ball milling was measured by a wattmeter (Yadu, Ltd., Shanghai, China). The wattmeter recorded the real-time power of the ball mill machine every second, and the energy consumption was calculated by integrating the recorded power over milling time:

$$
\mathrm{EM}=\frac{\int_{0}^{t} P_{t} \mathrm{~d} t}{m},
$$

where $\mathrm{EM}\left(\mathrm{kW} \mathrm{h} \mathrm{kg}^{-1}\right)$ is the energy consumption of ball milling, and converted to $\mathrm{MJ} \mathrm{\textrm {kg } ^ { - 1 }}$ with a coefficient of 3.6; $P_{t}(\mathrm{~kW})$ is the power of milling machine at time $\mathrm{t} ; m$ $(\mathrm{kg})$ is the mass of corn stover.

In a specific stirring tank, the energy dissipated by the impeller depends on the viscosity of the slurry when operating in the laminar and transition region (Reynolds number $\operatorname{Re}<10^{4}$ ) [26]. More specifically, the power consumption $P=N_{p}{ }^{*} \rho^{*} N^{3 *} D^{5}$, where $N_{p}$ is the impeller power number, $\rho$ the fluid density, $N$ the impeller speed, and $D$ the impeller diameter. And $N_{p}$ is a function of Reynolds number $\left(N_{p}=K^{*} \mathrm{Re}^{-1}=K^{*} \eta_{a} /\left(\rho^{*} N^{*} D^{2}\right)\right)$ [41], thus $P=K^{*} \eta_{a}{ }^{*} N^{2 *} D^{3}$, where $K$ is power constant; therefore, the power consumption for mixing is proportional to the apparent viscosity of the slurry at a specific stirred tank and stirring speed. Assumed that the EH was carried out in a 7-L conventional stirred tank equipped with a helical ribbon impeller $(D=0.185 \mathrm{~m})$ [42], then the energy consumption for mixing during $\mathrm{EH}$ could be estimated as described below. To save energy, the stirring speed is relatively low at high-solids EH, for example, the stirring speed in the pilot scale reactors of the NREL is $55 \mathrm{rpm}$ [14]. The corresponding effective shear rate is calculated by $\gamma_{\mathrm{eff}}=K_{s}{ }^{*} N$ [43], where $K_{s}$ is the Metzner constant and $K_{s}$ equal to 32.9 for the selected helical ribbon impeller [42]. Therefore, selected the apparent viscosity at $\gamma_{\text {eff }}=32.9 * 55 / 60=30.16 \mathrm{~s}^{-1}$ (according to the data exported from the instrument, data at $25.12 \mathrm{~s}^{-1}$ were chosen). According to the power consumption curve of helical ribbon impeller, the power constant $(K)$ was taken as 173.1 [42]. So far, the power consumption for stirring at different hydrolysis time could be estimated by $P=K * \eta_{a}^{*} N^{2 *} D^{3}$, and the energy consumption during the whole $\mathrm{EH}$ period $(48 \mathrm{~h}$ ) was calculated by integrating over time. 


\section{Supplementary information}

Supplementary information accompanies this paper at https://doi. org/10.1186/s13068-020-01717-9.

Additional file 1: Figure S1. Apparent viscosity as a function of shear rate and shear stress for BMCS slurry at different solids loading. Figure S2. Enzymatic hydrolysis kinetic data of ball-milled corn stover. Table S1. Free water amount for BMCS slurry at $30 \%$ solids loading

\section{Abbreviations}

EH: Enzymatic hydrolysis; BMCS: Ball-milled corn stover; SEM: Scanning electron microscope; XRD: X-ray diffraction; Crl: Crystallinity index; PV: Pore volume; SSA: Specific surface area; DP: Degree of polymerization.

\section{Acknowledgements}

Not applicable.

\section{Authors' contributions}

MSL conceived this study, designed and performed the experiments, analyzed the results, and wrote the manuscript. JBL assisted in the experimental analysis. LJH helped revise the paper. WHX coordinated the overall study and revised the manuscript. All authors read and approved the final manuscript.

\section{Funding}

This work was financially supported by the National Key R\&D Program of China [Project No. 2016YFE0112800] and the Program for Changjiang Scholars and Innovative Research Team in University of Ministry of Education of China [Project No. IRT-17R105]

\section{Availability of data and materials}

All data generated or analyzed during this study are included in this published article.

\section{Ethics approval and consent to participate}

Not applicable.

\section{Consent for publication}

Not applicable.

\section{Competing interests}

The authors declare that they have no competing interests.

Received: 18 February 2020 Accepted: 13 April 2020

Published online: 20 April 2020

\section{References}

1. Chen H, Fu X. Industrial technologies for bioethanol production from lignocellulosic biomass. Renew Sustain Energy Rev. 2016;57:468-78.

2. Nguyen TY, Cai CM, Kumar R, Wyman CE. Overcoming factors limiting high-solids fermentation of lignocellulosic biomass to ethanol. Proc Nat Acad Sci U S A. 2017;114(44):11673-8.

3. Xiros $C$, Janssen $M$, Byström $R$, Børresen BT, Cannella $D$, Jørgensen $H$, Koppram R, Larsson C, Olsson L, Tillman AM, et al. Toward a sustainable biorefinery using high-gravity technology. Biofuels Bioprod Biorefin. 2016;11(1):15-27.

4. Kristensen JB, Felby $\mathrm{C}$, Jorgensen $\mathrm{H}$. Yield-determining factors in high-solids enzymatic hydrolysis of lignocellulose. Biotechnol Biofuels. 2009;2(1):11.

5. Jorgensen $\mathrm{H}$, Vibe-Pedersen J, Larsen J, Felby C. Liquefaction of lignocellulose at high-solids concentrations. Biotechnol Bioeng 2007:96(5):862-70.

6. Larsen J, Østergaard Petersen M, Thirup L, Wen Li H, Krogh Iversen F. The IBUS process-lignocellulosic bioethanol close to a commercial reality. Chem Eng Technol. 2008;31(5):765-72.

7. Modenbach AA, Nokes SE. Enzymatic hydrolysis of biomass at high-solids loadings - a review. Biomass Bioenerg. 2013;56:526-44
8. Palmqvist B, Liden G. Torque measurements reveal large process differences between materials during high solid enzymatic hydrolysis of pretreated lignocellulose. Biotechnol Biofuels. 2012;5:57.

9. Zhang J, Chu DQ, Huang J, Yu ZC, Dai GC, Bao J. Simultaneous saccharification and ethanol fermentation at high corn stover solids loading in a helical stirring bioreactor. Biotechnol Bioeng. 2010;105(4):718-28.

10. Pimenova NV, Hanley AR. Effect of corn stover concentration on rheological characteristics. Appl Biochem Biotech. 2004;113:347-60.

11. Pimenova NV, Hanley TR. Measurement of rheological properties of corn stover suspensions. Appl Biochem Biotech. 2003;105:383-92.

12. Wiman M, Palmqvist B, Tornberg E, Liden G. Rheological characterization of dilute acid pretreated softwood. Biotechnol Bioeng. 2011:108(5):1031-41.

13. Stickel JJ, Knutsen JS, Liberatore MW, Luu W, Bousfield DW, Klingenberg DJ, Scott CT, Root TW, Ehrhardt MR, Monz TO. Rheology measurements of a biomass slurry: an inter-laboratory study. Rheol Acta. 2009;48(9):1005-15.

14. Viamajala S, McMillan JD, Schell DJ, Elander RT. Rheology of corn stover slurries at high solids concentrations-effects of saccharification and particle size. Bioresour Technol. 2009:100(2):925-34.

15. Ehrhardt MR, Monz TO, Root TW, Connelly RK, Scott CT, Klingenberg DJ. Rheology of dilute acid hydrolyzed corn stover at high solids concentration. Appl Biochem Biotechnol. 2010;160(4):1102-15.

16. Nguyen TC, Anne-Archard D, Fillaudeau L. Rheology of lignocellulose suspensions and impact of hydrolysis: a review. In: Krull R, Bley T, editors. Filaments in bioprocesses, vol. 149. Cham: Springer; 2015.

17. Dunaway KW, Dasari RK, Bennett NG, Berson RE. Characterization of changes in viscosity and insoluble solids content during enzymatic saccharification of pretreated corn stover slurries. Bioresour Technol. 2010;101(10):3575-82.

18. Roche CM, Dibble CJ, Knutsen JS, Stickel JJ, Liberatore MW. Particle concentration and yield stress of biomass slurries during enzymatic hydrolysis at high-solids loadings. Biotechnol Bioeng. 2009;104(2):290-300.

19. Ghosh S, Holwerda EK, Worthen RS, Lynd LR, Epps BP. Rheological properties of corn stover slurries during fermentation by Clostridium thermocellum. Biotechnol Biofuels. 2018;11:246.

20. Dasari RK, Eric Berson R. The effect of particle size on hydrolysis reaction rates and rheological properties in cellulosic slurries. Appl Biochem Biotechnol. 2007;137-140(1-12):289-99.

21. Ji G, Han L, Gao C, Xiao W, Zhang Y, Cao Y. Quantitative approaches for illustrating correlations among the mechanical fragmentation scales, crystallinity and enzymatic hydrolysis glucose yield of rice straw. Bioresour Technol. 2017;241:262-8.

22. Liu H, Chen X, Ji G, Yu H, Gao C, Han L, Xiao W. Mechanochemical deconstruction of lignocellulosic cell wall polymers with ball-milling. Bioresour Technol. 2019;286:121364.

23. Barakat A, Monlau F, Solhy A, Carrere H. Mechanical dissociation and fragmentation of lignocellulosic biomass: effect of initial moisture, biochemical and structural proprieties on energy requirement. Appl Energy. 2015;142:240-6.

24. Meng X, Ragauskas AJ. Recent advances in understanding the role of cellulose accessibility in enzymatic hydrolysis of lignocellulosic substrates. Curr Opin Biotechnol. 2014;27:150-8.

25. Hodge DB, Karim MN, Schell DJ, McMillan JD. Model-based fed-batch for high-solids enzymatic cellulose hydrolysis. Appl Biochem Biotechnol. 2009:152(1):88-107.

26. Palmqvist $B$, Wiman M, Liden $G$. Effect of mixing on enzymatic hydrolysis of steam-pretreated spruce: a quantitative analysis of conversion and power consumption. Biotechnol Biofuels. 2011;4:10.

27. Correa LJ, Badino AC, Cruz AJG. Mixing design for enzymatic hydrolysis of sugarcane bagasse: methodology for selection of impeller configuration. Bioproc Biosyst Eng. 2016;39(2):285-94.

28. Barakat A, de Vries H, Rouau X. Dry fractionation process as an important step in current and future lignocellulose biorefineries: a review. Bioresour Technol. 2013;134:362-73.

29. Inoue H, Yano S, Endo T, Sakaki T, Sawayama S. Combining hot-compressed water and ball milling pretreatments to improve the efficiency of the enzymatic hydrolysis of eucalyptus. Biotechnol Biofuels. 2008;1:2 
30. Licari A, Monlau F, Solhy A, Buche P, Barakat A. Comparison of various milling modes combined to the enzymatic hydrolysis of lignocellulosic biomass for bioenergy production: glucose yield and energy efficiency. Energy. 2016;102:335-42.

31. Lu MS, Li JB, Han LJ, Xiao WH. An aggregated understanding of cellulase adsorption and hydrolysis for ball-milled cellulose. Bioresour Technol. 2019;273:1-7.

32. Bals BD, Gunawan C, Moore J, Teymouri F, Dale BE. Enzymatic hydrolysis of pelletized AFEX-treated corn stover at high solid loadings. Biotechnol Bioeng. 2014;111(2):264-71.

33. Cara C, Moya M, Ballesteros I, Negro MJ, González A, Ruiz E. Influence of solid loading on enzymatic hydrolysis of steam exploded or liquid hot water pretreated olive tree biomass. Process Biochem. 2007;42(6):1003-9.

34. Du J, Cao Y, Liu G, Zhao J, Li X, Qu Y. Identifying and overcoming the effect of mass transfer limitation on decreased yield in enzymatic hydrolysis of lignocellulose at high solid concentrations. Bioresour Technol. 2017;229:88-95.

35. Klinke HB, Thomsen AB, Ahring BK. Inhibition of ethanol-producing yeast and bacteria by degradation products produced during pre-treatment of biomass. Appl Microbiol Biotechnol. 2004;66(1):10-26.

36. Koppram R, Tomas-Pejo E, Xiros C, Olsson L. Lignocellulosic ethanol production at high-gravity: challenges and perspectives. Trends Biotechnol. 2014;32(1):46-53.

37. Bradford MM. A rapid and sensitive method for the quantitation of microgram quantities of protein utilizing the principle of protein-dye binding. Anal Biochem. 1976;72:248-54.
38. Sluiter A, Hames B, Ruiz R, Scarlata C, Sluiter J, Templeton D, Crocker D. Determination of structural carbohydrates and lignin in biomass. National Renewable Energy Laboratory Technical Report NREL/TP-510-42618, 2008.

39. Segal L, Creely JJ, Martin AE, Conrad CM. An empirical method for estimating the degree of crystallinity of native cellulose using the X-Ray diffractometer. Text Res J. 1959;29(10):786-94.

40. Sluiter A, Hames B, Ruiz R, Scarlata C, Sluiter J, Templeton D. Determination of sugars, byproducts, and degradation products in liquid fraction process samples. National Renewable Energy Laboratory Technical Report NREL/TP-510-42623, 2008.

41. Carreau PJ, Chhabra RP, Cheng J. Effect of rheological properties on power-consumption with helical ribbon agitators. AlChE J. 1993;39(9):1421-30.

42. BritodelaFuente E, Choplin L, Tanguy PA. Mixing with helical ribbon impellers: effect of highly shear thinning behaviour and impeller geometry. Chem Eng Res Des. 1997;75(A1):45-52.

43. Metzner AB, Otto RE. Agitation of non-newtonian fluids. AIChE J. 1957;3(1):3-10.

\section{Publisher's Note}

Springer Nature remains neutral with regard to jurisdictional claims in published maps and institutional affiliations.
Ready to submit your research? Choose BMC and benefit from:

- fast, convenient online submission

- thorough peer review by experienced researchers in your field

- rapid publication on acceptance

- support for research data, including large and complex data types

- gold Open Access which fosters wider collaboration and increased citations

- maximum visibility for your research: over 100M website views per year

At BMC, research is always in progress.

Learn more biomedcentral.com/submissions 